\title{
Obtaining sub-daily new snow density from automated measurements in high mountain regions
}

\author{
Kay Helfricht ${ }^{1}$, Lea Hartl ${ }^{1}$, Roland Koch ${ }^{2}$, Christoph Marty ${ }^{3}$, and Marc Olefs ${ }^{2}$ \\ ${ }^{1}$ IGF - Institute for Interdisciplinary Mountain Research, Austrian Academy of Sciences, Innsbruck, 6020, Austria \\ ${ }^{2}$ ZAMG - Zentralanstalt für Meteorologie und Geodynamik, Climate research department, 1190 Vienna, Austria \\ ${ }^{3}$ WSL Institute for Snow and Avalanche Research SLF, 7260 Davos, Switzerland
}

Correspondence: Kay Helfricht (kay.helfricht@oeaw.ac.at)

Received: 25 September 2017 - Discussion started: 6 October 2017

Revised: 6 April 2018 - Accepted: 20 April 2018 - Published: 4 May 2018

\begin{abstract}
The density of new snow is operationally monitored by meteorological or hydrological services at daily time intervals, or occasionally measured in local field studies. However, meteorological conditions and thus settling of the freshly deposited snow rapidly alter the new snow density until measurement. Physically based snow models and nowcasting applications make use of hourly weather data to determine the water equivalent of the snowfall and snow depth. In previous studies, a number of empirical parameterizations were developed to approximate the new snow density by meteorological parameters. These parameterizations are largely based on new snow measurements derived from local in situ measurements. In this study a data set of automated snow measurements at four stations located in the European Alps is analysed for several winter seasons. Hourly new snow densities are calculated from the height of new snow and the water equivalent of snowfall. Considering the settling of the new snow and the old snowpack, the average hourly new snow density is $68 \mathrm{~kg} \mathrm{~m}^{-3}$, with a standard deviation of $9 \mathrm{~kg} \mathrm{~m}^{-3}$. Seven existing parameterizations for estimating new snow densities were tested against these data, and most calculations overestimate the hourly automated measurements. Two of the tested parameterizations were capable of simulating low new snow densities observed at sheltered inner-alpine stations. The observed variability in new snow density from the automated measurements could not be described with satisfactory statistical significance by any of the investigated parameterizations. Applying simple linear regressions between new snow density and wet bulb temperature based on the measurements' data resulted in significant relationships $\left(r^{2}>0.5\right.$ and $\left.p \leq 0.05\right)$ for single periods at in-
\end{abstract}

dividual stations only. Higher new snow density was calculated for the highest elevated and most wind-exposed station location. Whereas snow measurements using ultrasonic devices and snow pillows are appropriate for calculating station mean new snow densities, we recommend instruments with higher accuracy e.g. optical devices for more reliable investigations of the variability of new snow densities at sub-daily intervals.

\section{Introduction}

In mountain regions there is an increasing demand for highquality analysis, nowcasting and short-range forecasts of the spatial distribution of snowfall. Operational services, concerning avalanche warning, road maintenance and hydrology, as well as hydropower companies and ski resorts, need reliable information on the depth of new snow $(\mathrm{HN})$ and the water equivalent (HNW) of snowfall. Therefore the new snow density $\left(\rho_{\mathrm{HN}}\right)$ is needed to convert $\mathrm{HN}$ into HNW and vice versa. Information on $\mathrm{HN}$ is especially relevant for cold and windy conditions, when measuring HNW is a difficult task because conventional rain gauge measurements are prone to large errors (e.g. Goodison et al., 1998). Recent results of the Solid Precipitation Intercomparison Experiment (SPICE; Nitu et al., 2012) reveal that these errors still exist in standard meteorological measurements (e.g. Buisán et al., 2016; Pan et al., 2016). Many snow cover models calculate HN from HNW at sub-daily time intervals, although reliable HNW input data are difficult to obtain (Egli et al., 2009), and thus the new snow density is needed in equal temporal resolution 
to convert between HNW and HN (e.g. Lehning et al., 2002; Roebber et al., 2003; Olefs et al., 2013). Additionally, $\rho_{\mathrm{HN}}$ has a considerable effect on the snow bulk density of the total snowpack (e.g. Schöber et al., 2016).

Since the 1960s ultrasonic rangers have become more common for observing snow depth changes automatically even at sub-hourly time intervals (e.g. Gubler, 1981; Goodison et al., 1984; Lundberg et al., 2010). They have the advantage of a more objective method compared to subjective manual measurements of snow depth (Ryan et al., 2008). Although high-accuracy optical snow depth sensors have been more frequently used in practice over recent years (e.g. Mair and Baumgartner, 2010; Helfricht et al., 2016), longer time series of snow depths exist from ultrasonic measurements. Beside snow depth (HS), the water equivalent of the snowpack (SWE) is observed operationally using weighing devices such as lysimetric snow pillows (e.g. Serreze et al., 1999; Egli et al., 2009; Lundberg et al., 2010; Krajči et al., 2017) and snow scales (e.g. http://www. sommer.at/en/products/snow-ice/snow-scales-ssg-2, last access: 3 May 2018). Upward-looking GPR (e.g. Heilig et al., 2009) and GPS techniques (e.g. Koch et al., 2014; McCreight et al., 2014) and the combination of both (Schmid et al., 2015) have been applied in scientific studies to monitor the depth, SWE and liquid water content of the snowpack. However, these techniques are rather expensive or not yet in use for long-term observations by operational services. In general, automatic measurements of SWE are prone to a high relative uncertainty and require a certain degree of maintenance, which makes them complex and labour-intensive (Smith et al., 2017). Due to such constraints, SWE measurement instrumentation is installed at considerably fewer stations compared to HS instruments, and only at sites with easy access for appropriate maintenance. Recent studies present the performance of cosmic ray neutron sensors (e.g. Schattan et al., 2017), which are partly used for long-term observations such as e.g. from Col de Porte (Morin et al., 2012).

The density of new snow is influenced by the shape and size of the snow crystals (e.g. Nakaya, 1951). Relationships between predominant snow crystal type, riming properties and snowfall density were already reported by Power et al. (1964) from snowstorm observations in Canada. Once the snow crystals have accumulated at the snow surface, the density of the fresh snow starts to increase depending on prevailing weather conditions and compaction caused by overlaying of snow. A common mean $\rho_{\mathrm{HN}}$ used to convert between $\mathrm{HN}$ and $\mathrm{HNW}$ is $100 \mathrm{~kg} \mathrm{~m}^{-3}$. Many studies analysed $\rho_{\mathrm{HN}}$ values on a daily basis and confirmed this $10: 1$ rule as applicable for a first estimate (e.g. Roebber et al., 2003; Egli et al., 2009; Teutsch, 2009). However, $\rho_{\mathrm{HN}}$ values span a wide range, and values from 10 to $350 \mathrm{~kg} \mathrm{~m}^{-3}$ have been reported from American and European mountain ranges, with mean values between 70 and $110 \mathrm{~kg} \mathrm{~m}^{-3}$ (e.g. Diamond and Lowry, 1954; LaChapelle, 1962; Power et al., 1964; Judson, 1965; McKay et al., 1981; Meister, 1985; Judson and Doesken, 2000; Valt et al., 2014). Most of the $\rho_{\mathrm{HN}}$ data analysed in these studies were observed using readings on a snow board. The density is calculated from HN measured with a ruler and HNW is derived from an external precipitation device or from weighing the new snow either in solid or melted form (Fierz et al., 2009).

Several studies have shown that measured $\rho_{\mathrm{HN}}$ can be related to meteorological parameters, although with different time intervals and different degrees of determination. Gold and Power (1952) showed that the crystal type is related to its estimated formation temperature. Diamond and Lowry (1954) and Simeral et al. (2005) built an empirical calculation that ascertained relationships between $\rho_{\mathrm{HN}}$ and air temperature at the $700 \mathrm{mb}$ level. Teutsch (2009) also concluded that $\rho_{\mathrm{HN}}$ of $12 \mathrm{~h}$ intervals at valley stations is best correlated to the wet bulb temperature at mountain stations in close vicinity $\left(r^{2}=0.86\right)$. Judson and Doesken (2000) found that near-surface air temperature and new snow density at mountain stations could explain $52 \%$ of the variance in snow density. Wetzel et al. (2004) presented a similar degree of correlation of $\rho_{\mathrm{HN}}$ to temperature at three high-elevation sites. Alcott and Steenburg (2010) showed that $\rho_{\mathrm{HN}}$ is correlated with near-crest-level temperature and wind speed particularly for high-SWE events. Wright et al. (2016) presented a statistical analysis of data from 42 seasons of manual daily snow density measurements along with air temperature and wind speed to derive parameterizations to estimate new snow density. However, they end up with a low coefficient of determination.

On the basis of data from seven stations in Switzerland located between 1250 and $1800 \mathrm{~m}$ a.s.l., Meister (1985) concluded that $\rho_{\mathrm{HN}}$ does not correlate with the amount of new snow (HN), that it does not depend on altitude and that air temperature does not accurately determine $\rho_{\mathrm{HN}}$. Nevertheless, binning the data into temperature classes results in a statistical equation with a correlation coefficient of 0.85 . Further, he recommended considering wind speed in addition to air temperature, at least for stations higher than $1800 \mathrm{~m}$ a.s.l. On the basis of data sets from Schmidt and Gluns (1991) and the US Army Corps of Engineers (1956), Hedstrom and Pomeroy (1998) developed a power function using the air temperature, for which they found a coefficient of determination of 0.84 and a standard error of estimate of $9.3 \mathrm{~kg} \mathrm{~m}^{-3}$. Jordan et al. (1999) introduced an algorithm for assigning $\rho_{\mathrm{HN}}$ within the SNTHERM snow cover model. They added wind dependence to the temperature parameterization of Meister (1985). This achieved a reduction of the error, but a significant scatter remained between observed and parameterized $\rho_{\mathrm{HN}}$ values. Lehning et al. (2002) built an empirical calculation for $\rho_{\mathrm{HN}}$ valid for a time interval of 30 to $60 \mathrm{~min}$ in the framework of the snow model SNOWPACK. They used air temperature, surface temperature, relative humidity and wind speed for the regression analysis and achieved an approximate multiple coefficient of determination of 0.83 . Schmucki et al. (2014) used another empirical power rela- 
tion, including air temperature, wind speed and relative humidity, to calculate the $\rho_{\mathrm{HN}}$ using SNOWPACK simulations for three contrasting sites in Switzerland. $\rho_{\mathrm{HN}}$ was analysed in short time intervals of $1-2 \mathrm{~h}$ by Ishizaka et al. (2016). They measured even lower densities in comparison to $\rho_{\mathrm{HN}}$ estimates obtained using the SNOWPACK density model, especially for aggregated snow crystal types. On the basis of data from Col de Porte (1325 m altitude, French Alps), Pahaut et al. (1976) developed a statistical relationship including the melting point of water, air temperature and wind speed. This parameterization is used to calculate the density of new snow in the snow cover model CROCUS (Vionnet et al., 2012).

Settling of the new snow by its weight and destructive metamorphism may reduce $\mathrm{HN}$ and hence increase $\rho_{\mathrm{HN}}$ between snowfall and the $\mathrm{HN}$ reading and has to be considered when computing new snow density (e.g. Anderson, 1976; Lehning et al., 2002; Steinkogler, 2009; Vionnet et al., 2012). The contribution of settling to snow depth changes is highest in the first hours after snowfall. Wind drift and radiation input to the snow surface after the snowfall may increase $\rho_{\mathrm{HN}}$ in comparison to $\rho_{\mathrm{HN}}$ at the time of snowfall. However, direct measurements of $\rho_{\mathrm{HN}}$ at the time of snowfall are laborious and difficult to align with the hours of peak snowfall rates.

Whereas most of the studies have analysed daily and subdaily, manual $\rho_{\mathrm{HN}}$ measurements, to the best of our knowledge no extensive analysis of automated $\rho_{\mathrm{HN}}$ measurements in hourly intervals over several winter seasons exists. The aim of this study is to assess the value of automated measurements of hourly $\mathrm{HN}$ and HNW for the calculation of $\rho_{\mathrm{HN}}$ at different stations and at hourly time intervals. Therefore we examine the following questions.

1. Are automated measurements of $\mathrm{HN}$ and HNW suitable for the calculation of $\rho_{\mathrm{HN}}$ at hourly intervals?

2. How do the mean and the variability of observed $\rho_{\mathrm{HN}}$ differ between distinct study sites?

3. How well do established density parameterizations represent observed hourly $\rho_{\mathrm{HN}}$ values?

To this end, we calculated $\rho_{\mathrm{HN}}$ from hourly snow depth changes (HN) and hourly SWE changes (HNW). The mean values and the variability of hourly $\rho_{\mathrm{HN}}$ are discussed for observations at four different meteorological stations and compared to calculations using established $\rho_{\mathrm{HN}}$ parameterizations. A critical assessment with an outlook for nextgeneration measurement techniques is given in the discussion.

\section{Data and methods}

Data from four automatic weather stations (AWSs) were used in this study (Fig. 1, Table 1). A prerequisite for the station selection was the combined measurement of HS and SWE at each station in addition to the standard meteorological measurements of air temperature, relative humidity, precipitation, wind speed and global radiation. HS data are measured using ultrasonic rangers. SWE data are recorded using snow pillows. Details regarding the instruments at each AMS and the exact location of each AWS, as well as the start and end dates of the available data coverage, are presented in Table 1.

The Kühroint station (Germany) is operated by the Bavarian Avalanche Warning Service. It is a well-equipped and maintained station for snow climate at the northern fringe of the eastern Alps. It is located in a meadow below the tree line.

The Kühtai station (Austria) is operated by the Tiroler Wasserkraft AG (TIWAG). It is located south of the Inntal valley, but north of the Alpine main ridge, and it is situated in a wind-sheltered location.

The station at Wattener Lizum (Austria) is operated by the Austrian Research Centre for Forests (BFW) of the Federal Ministry of Agriculture, Forestry, Environment and Water Management. This station is situated in a south-northoriented high alpine valley above the tree line near to the Alpine main ridge. This station has an exceptionally long time series of snow-hydrological measurements (Krajči et al., 2017; Parajka, 2017).

The station at Weissfluhjoch (Switzerland) is operated by the Institute for Snow and Avalanche Research (SLF), which is part of the Swiss Federal Institute for Forest, Snow and Landscape Research (WSL). The station is presented in more detail by Marty and Meister (2012). Weissfluhjoch is the highest elevated station considered in this study.

On the basis of coinciding data availability we consider four time periods as presented in Table 1. Data outputs of the AWSs are logged at time intervals ranging from 2 to $30 \mathrm{~min}$. Hourly values were computed for global radiation, relative humidity, air temperature and wind speed. The hourly value is the mean of the previous hour. For precipitation it is the sum of the previous hour. To account for noise in the ultrasonic signal, HS and SWE were smoothed using a centred moving average over three values in the original data resolution. The hourly values for HS and SWE are the values from the smoothed time series.

The thermodynamic wet bulb temperature $\left(T_{\mathrm{w}}\right)$ was computed applying the psychrometric equation (Sonntag, 1990) and an exact iterative approach presented by Olefs et al. (2010). A standard barometric equation was used to determine air pressure based on the station elevation. Air pressure dependency of $T_{\mathrm{w}}$ is generally minor and only relevant for air temperatures larger than $+2{ }^{\circ} \mathrm{C}$ (Olefs et al., 2010).

A necessary condition for all further analysis of the time series was the presence of a precipitation signal at the heated precipitation gauges in combination with positive snow depth changes. Then, the hourly height of new snow $(\mathrm{HN})$ and the water equivalent of snowfall (HNW) were computed as the change in HS and SWE. Within the next filtering step, only 


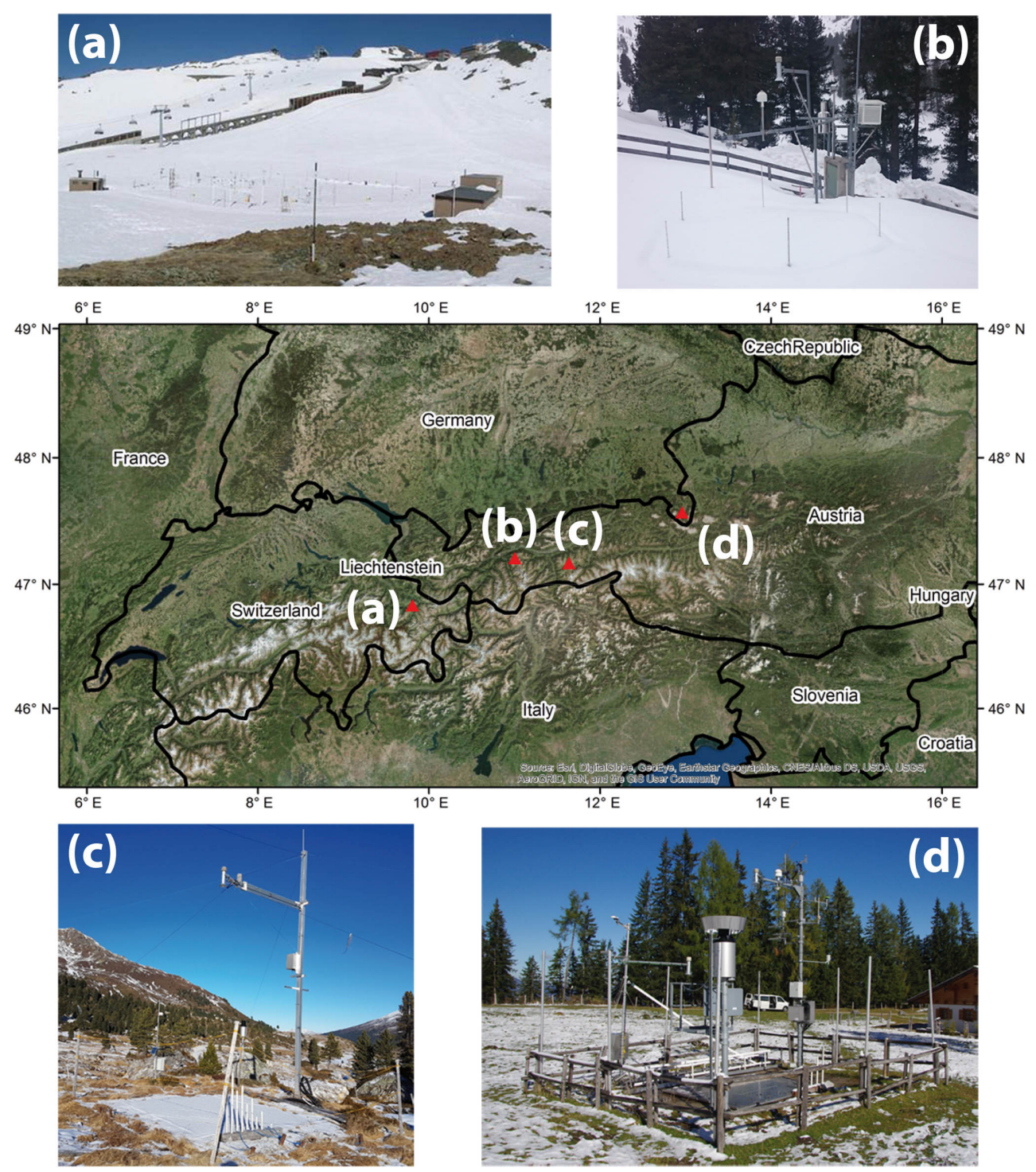

Figure 1. Map of the station locations. Pictures are given for (a) Weissfluhjoch station, (b) Kühtai station, (c) Wattener Lizum station and (d) Kühroint station.

$\mathrm{HN}$ and $\mathrm{HNW}$ values with $T_{\mathrm{w}}$ less than $0{ }^{\circ} \mathrm{C}$ and a wind speed (u) of less than $5 \mathrm{~m} \mathrm{~s}^{-1}$ were considered.

Constraints have to be set in order to avoid low values of $\mathrm{HNW}$ and $\mathrm{HN}$, which are prone to large relative errors due to random and systemic measurement uncertainties in $\mathrm{HN}$ and SWE, but a minimum of approx. 100 remaining samples for statistical analysis must be ensured.

To investigate the influence of different minimum HNW and $\mathrm{HN}$ limits, a distribution matrix was calculated by varying the minimum $\mathrm{HNW}$ and $\mathrm{HN}$ limits in steps of $0.5 \mathrm{~mm}$ for HNW and $0.5 \mathrm{~cm}$ for HN, respectively. To account for settling during ongoing snowfall, the compaction correction described in Anderson (1976) was applied. The approach was simplified with respect to HS, SWE and snow density by considering only two layers of the snowpack: the new snow and the total snowpack of the previous time step. Destructive settling $(S)$ of $\mathrm{HN}$ is considered for each time step in which the snow depth increases (Eq. 1). The destructive settling of the new snow $\left(S_{\mathrm{HN}}\right)$ for each time step is calculated by

$$
\begin{aligned}
& S_{\mathrm{HN}}=-0.000002777 \cdot e^{(0.04 \cdot T)}\left\{\rho_{\mathrm{HN}} \leq 150 \mathrm{~kg} \mathrm{~m}^{-3}\right\} \\
& S_{\mathrm{HN}}=S_{\mathrm{HN}} \cdot e^{\left(0.046 \cdot T \cdot\left(\rho_{\mathrm{HN}}-150\right)\right)}\left\{\rho_{\mathrm{HN}} \geq 150 \mathrm{~kg} \mathrm{~m}^{-3}\right\},
\end{aligned}
$$

where $T$ is the air temperature. Settling of the new snow layer caused by the weight of the ongoing snow accumulation is not taken into account.

Settling within the old snowpack is computed considering the total snow depth (HS). The destructive settling within the old snow layer $\left(S_{\mathrm{HS}}\right)$ is calculated using Eq. (1), substituting HS for $\mathrm{HN}$ and using the bulk density of the old snowpack 
Table 1. Coordinates and data availability are given for the four snow stations. The instrumentation for measuring snow depth (HS), snow water equivalent (SWE), temperature $(T)$, relative humidity $(\mathrm{RH})$, precipitation $(P)$, wind speed $(u)$ and global radiation $(r)$ is listed.

\begin{tabular}{|c|c|c|c|c|c|}
\hline \multicolumn{2}{|c|}{ Station abbreviation } & \multirow{2}{*}{$\begin{array}{l}\text { Kühroint } \\
\text { KRO }\end{array}$} & \multirow{2}{*}{$\begin{array}{l}\text { Kühtai } \\
\text { KTA }\end{array}$} & \multirow{2}{*}{$\begin{array}{l}\text { Wattener Lizum } \\
\text { WAL }\end{array}$} & \multirow{2}{*}{$\begin{array}{l}\text { Weissfluhjoch } \\
\text { WFJ }\end{array}$} \\
\hline & & & & & \\
\hline \multirow[t]{3}{*}{ Location } & East & $12^{\circ} 57^{\prime} 35.5^{\prime \prime}$ & $11^{\circ} 00^{\prime} 21.6^{\prime \prime}$ & $11^{\circ} 38^{\prime} 18.6^{\prime \prime}$ & $9^{\circ} 48^{\prime} 35.7^{\prime \prime}$ \\
\hline & North & $47^{\circ} 34^{\prime} 12.4^{\prime \prime}$ & $47^{\circ} 12^{\prime} 25.6^{\prime \prime}$ & $47^{\circ} 10^{\prime} 05.5^{\prime \prime}$ & $46^{\circ} 49^{\prime} 46.4^{\prime \prime}$ \\
\hline & $z$ (m a.s.l.) & 1420 & 1970 & 1994 & 2540 \\
\hline \multicolumn{2}{|c|}{ Data } & 1 Jan 2011- & 27 Feb 1987- & 1 Oct 2010 & 1 Oct 2013- \\
\hline \multirow{7}{*}{ Instruments } & HS & COMmOLUP & Sommer USH 8 & Sommer ISH \& & Camphell Scientific SR $50 \mathrm{~A}$ \\
\hline & SWE & Sommer Snow Scale SSG & $\begin{array}{l}\text { OTT Thalimedes Shaft En- } \\
\text { coder, Endress + Hauser } \\
\text { Deltapilot M }\end{array}$ & Sommer Snowpillow & Sommer Snowpillow \\
\hline & $\mathrm{T}$ & Rotronic MP408 & Kroneis NTC & Vaisala HMP45C & Rotronic Hydroclip S3 \\
\hline & $\mathrm{RH}$ & Rotronic MP408 & Pernix hair hygrometer & Vaisala HMP45C & Rotronic Hydroclip S3 \\
\hline & $\mathrm{P}$ & Sommer NIWA/Med-K505 & $\begin{array}{l}\text { Ott Pluvio since } 2001 \text {, custom } \\
\text { built tipping bucket before }\end{array}$ & Sommer NIWA/Med-K505 & Lambrecht Pluvio 1518 H3 \\
\hline & $u$ & Young 05103 & $\begin{array}{l}\text { Kroneis cup anemometer }+ \\
\text { vane }\end{array}$ & YOUNG Wind Monitor & Young 05103 \\
\hline & $\mathrm{r}$ & Schenk 8101 & Schenk 8101 & Kipp\&Zonen CM21 & Kipp\&Zonen CM21 \\
\hline \multicolumn{2}{|c|}{ Comments } & & $\begin{array}{l}\text { Data gap winter 2012/13, wind } \\
\text { regionalized from } 1999\end{array}$ & $\begin{array}{l}\text { Meteorological measurements } \\
\text { at } 2041 \mathrm{~m} \text { a.s.l. }\end{array}$ & \\
\hline
\end{tabular}

$\left(\rho_{\mathrm{HS}}\right)$ calculated from HS and total SWE of the previous time step. Settling within the old snowpack caused by the weight of the snowpack $\left(S_{\mathrm{wHS}}\right)$ is given as

$S_{\mathrm{wHS}}=-248.976 \cdot \frac{\mathrm{HN}}{3600000} \cdot e^{0.8 \cdot T} \cdot e^{-0.021 \cdot \rho_{\mathrm{HS}}}$.

The resulting settling factors of $S_{\mathrm{HN}}, S_{\mathrm{HS}}$ and $S_{\mathrm{wHS}}$ are multiplied by $\mathrm{HS}$ and $\mathrm{HN}$ to adjust $\mathrm{HN}$ accordingly.

New snow density $\left(\rho_{\mathrm{HN}}\right)$ was obtained from the ratio of $\mathrm{HN}$ to HNW. Outliers below the $5 \%$ percentile and higher than the $95 \%$ percentile were excluded. The $\rho_{\mathrm{HN}}$ data were grouped by wet bulb temperature and wind speed, using bins of $1{ }^{\circ} \mathrm{C}$ and $0.5 \mathrm{~ms}^{-1}$ respectively. A least squares regression was carried out using both the ungrouped data and the median of the grouped data to quantify possible correlations of $\rho_{\mathrm{HN}}$ with $T_{\mathrm{w}}$ and $u$.

The $\rho_{\mathrm{HN}}$ values were compared to the following parameterizations developed in previous studies. In these parameterizations, $\rho_{\mathrm{HN}}$ is a function of meteorological parameters such as air temperature $(T)$, wind speed $(u)$ and relative humidity (RH). The time interval for $\rho_{\mathrm{HN}}$ readings of the respective study is given in brackets.

$\rho_{\mathrm{HP}}=67.92+51.52 \cdot e^{\frac{T}{2.59}}$ (Hedstrom and Pomeroy 1998,

event/daily)

$\rho_{\mathrm{D}}=119+6.48 T$ (Diamond and Lowry 1954,

frequent interval during event)

$\rho_{\mathrm{LC}}=50+1.7 \cdot(T+15)^{1.5}($ LaChapelle 1962 , event $)$

$\rho_{J}=500 \cdot\left(1-0.951 \cdot \mathrm{e}^{-1.4 \cdot(5-T)^{-1.15}-0.008 u^{1.7}}\right)$

$\left\{-13^{\circ} \mathrm{C}<T \leq 2.5^{\circ} \mathrm{C}\right\}$
$\rho_{J}=500 \cdot\left(1-0.904 \cdot e^{-0.008 u^{1.7}}\right)\left\{T \leq 13^{\circ} \mathrm{C}\right\}$

(Jordan et al., 1999, event/daily)

$\rho_{V}=109+6 \cdot\left(T-T_{f}\right)+26 u^{0.5}$

(Vionnet et al., 2012, event/daily)

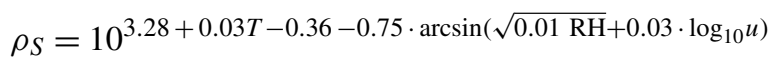

$\left\{T \geq-14^{\circ} \mathrm{C}\right\}$

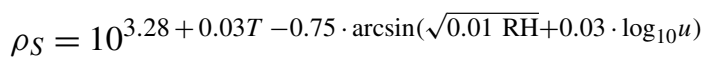

$\left\{T<-14^{\circ} \mathrm{C}\right\}$ (Schmucki et al., 2014, event/hourly)

$\rho_{\mathrm{L}}=70+6.5 T+7.5 T_{\mathrm{s}}+0.26 \mathrm{RH}+13 u-4.5 T T_{\mathrm{s}}$

$-0.65 T u-0.17 \mathrm{RH} u+0.06 T T_{\mathrm{s}} \mathrm{RH}$

(Lehning et al., 2002, event/hourly)

The melting point of snow $\left(T_{f}\right)$ in Eq. (7) was approximated as $0{ }^{\circ} \mathrm{C}$ (Vionnet et al., 2012). Following Schmucki et al. (2014), we limited the parameter range and set RH to a constant value of $0.8(80 \%)$ during snowfall and the lower boundary for the wind speed to $2 \mathrm{~ms}^{-1}$.

The temperature of the snow surface $\left(T_{\mathrm{S}}\right)$ is required in Eq. (9). As this was not available for each station, we used the approximation $T_{\mathrm{S}}=T$. We argue that $T_{\mathrm{S}}$ could not considerably exceed $0^{\circ}$ because of the maximum $T_{\mathrm{w}}$ of $0^{\circ} \mathrm{C}$. Since only precipitation events are considered, $\mathrm{RH}$ can be expected to be high, and thus the difference between $T_{\mathrm{w}}$ and $T$ is small.

The uncertainty of ultrasonic measurements on snow can be assumed to be in the range of $\pm 1 \mathrm{~cm}$, which is partly a consequence of changes in signal velocity due to meteorological conditions. However, we used the original HS data logged in millimetre resolution to avoid the effects caused 
by rounding to full centimetre when calculating HN. Likewise, we used the tenths of millimetre SWE data logged at the pillows. Another documented error source of the HS measurement is signal blocking by e.g. dense snowfall or drifting snow, which causes peaks of the HS. However, with the filtering procedure applied in this study, no such spikes were left in the analysis.

A source of uncertainty is the spatial offset between the HS measurements and the SWE measurements. HS is measured directly above the SWE measurement at Kühtai station, Kühroint station and Wattener Lizum station (Fig. 1). However, the footprint of the snow depth sensor may be smaller than the surface area of the pillow, and it decreases with increasing HS. A spatial variability of HS on the pillow can be caused by snow drift and differing snow settling or snowmelt.

For the calculations within this study we used the changes in HS and SWE over the time period of snowfall only. Errors due to spatial variability in HS and SWE caused by spatial differences in energy consumption and snow drift between precipitation events are reduced. This is especially valid for the HS and SWE measurements at the stations with matching HS and SWE measurements. The snow depth sensor and the snow pillow of Weissfluhjoch station are separated by $9 \mathrm{~m}$. Schmid et al. (2014) suggest a small-scale variability in HS of $\pm 4.3 \%$ at the Weissfluhjoch station. Again, the error may be smaller due to using temporally limited changes of HS, but an additional uncertainty of $\pm 5 \%$ can be assumed here.

A well-known issue with snow pillows is bridging effects (e.g. Serreze et al., 1999; Johnson and Schaefer, 2002). Dense snow layers and crusts within the snowpack sustain the weight of the new snow so that HNW, and thus $\rho_{\mathrm{HN}}$, are underestimated. We cannot exclude such data explicitly. However, all filtering conditions have to be fulfilled to include values in the analysis, so that data without or with lagged $\mathrm{HN}$ increase were not considered. Additionally, the chosen snow stations are well maintained in case of implausible data due to their overall good accessibility; e.g. trenches are dug out around the base area of the snow pillow at Kühtai station to cut off the measured part of the snowpack to avoid bridging effects.

Nevertheless, the measurement uncertainty is $\pm 1 \mathrm{~cm}$ for $\mathrm{HN}$ and $0.1 \mathrm{~cm}$ for HNW. Considering mean HN (Table 2) and HNW values, the uncertainty is $\pm 25 \mathrm{~kg} \mathrm{~m}^{-3}$ or $37 \%$ of the mean density. This value is lower considering higher $\mathrm{HN}$, but increases to $80 \%$ for the combination of minimum HN and minimum HNW of 1.6 and $0.2 \mathrm{~mm}$ respectively.

\section{Results and discussion}

\subsection{Data filtering, correction of settling and evaluation}

Figure 2 presents the median new snow density $\left(\rho_{\mathrm{HN}}\right)$ data calculated from all filtered HN and HNW values exceeding the respective minimum HN and HNW limits. This presenta-
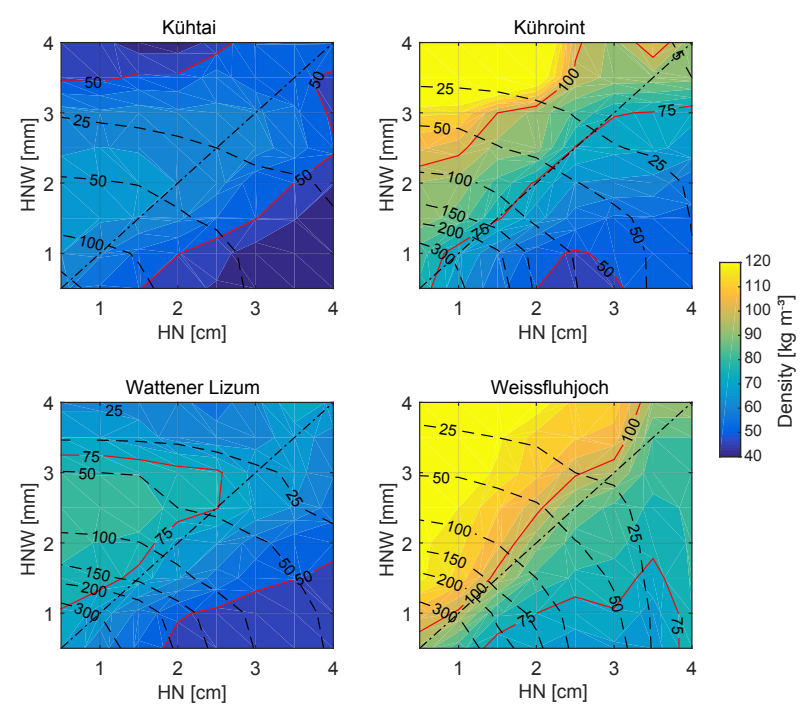

Figure 2. Median new snow densities (colour scale) calculated using all data exceeding different minimum limits of the height of new snow (HN) and the water equivalent of snowfall (HNW) for period 1 (1 October 2013-20 May 2015). Note that multiples of $25 \mathrm{~kg} \mathrm{~m}^{-3}$ are highlighted with red contour lines. The labelled black dashed lines give the count of the hourly data remaining after filtering. The straight dotted and dashed lines show results for equal minimum limits of $\mathrm{HN}(\mathrm{cm})$ and HNW (mm).

tion highlights the variability of $\rho_{\mathrm{HN}}$ by using different minimum limits with respect to the high relative uncertainty of low $\mathrm{HN}$ and $\mathrm{HNW}$ values. Changing the minimum limits for $\mathrm{HN}$ and HNW affects the resulting $\rho_{\mathrm{HN}}$ considerably. However, increasing the minimum limits for $\mathrm{HN}$ and HNW results in a distinct lowering of the number of data remaining for the subsequent analysis (Fig. 2). There are certain differences between the stations for high minimum HNW limits. Calculated $\rho_{\mathrm{HN}}$ decrease when low minimum $\mathrm{HN}$ and high minimum HNW limits are applied at Kühtai and Wattener Lizum station. In contrast, $\rho_{\mathrm{HN}}$ values increase for equal minimum limits at Kühroint and Weissfluhjoch stations. At Kühtai and Wattener Lizum stations, high HNW values of more than $3 \mathrm{~mm} \mathrm{HNW}$ are accompanied by a rather high HN (Fig. 2). In contrast, a low HN occurring with a high HNW at Kühroint and Weissfluhjoch causes a high $\rho_{\mathrm{HN}}$. However, these results are based on a small number of values only. In general, the calculated median $\rho_{\mathrm{HN}}$ values are rather constant following the 1: 1 line of minimum HNW and HN limits (Fig. 2).

In order to avoid low values of HNW and HN, but ensuring an appropriate number of approx. 100 samples and with respect to the results of the Fig. 2, we decided to use a minimum limit of $1.5 \mathrm{~mm}$ in $\mathrm{HNW}$ and $2.0 \mathrm{~cm}$ in HN. This leads to the exclusion of on average $94 \%$ of all data points that have a precipitation signal and positive snow depth changes (Table 2). Frequency distributions for HN, HNW, $T_{\mathrm{w}}$ and $u$ of the unfiltered and filtered data are presented for each sta- 
Table 2. Time periods analysed in this study with the mean and the median of hourly values for the height of new snow (HN), wet bulb temperature $\left(T_{\mathrm{W}}\right)$, wind speed $(u)$, calculated densities from observed values $(\rho)$ and calculated densities corrected for settling of the snowpack $\left(\rho_{\mathrm{HN}}\right)$. The results are valid for the filtered data values $\left(n_{\mathrm{th}}\right)$ with $\mathrm{HN}>2 \mathrm{~cm}, \mathrm{HNW}>1.5 \mathrm{~mm}, T_{\mathrm{W}}<0{ }^{\circ} \mathrm{C}$ and $u<5 \mathrm{~ms}^{-1}$ as a subset of all data that have a precipitation signal and positive HS change $\left(n_{\mathrm{P}}\right)$.

\begin{tabular}{|c|c|c|c|c|c|c|c|c|c|c|c|c|c|c|}
\hline \multirow[t]{2}{*}{ Station } & \multicolumn{2}{|c|}{ Period } & \multicolumn{2}{|c|}{ Count data } & \multicolumn{2}{|c|}{$\mathrm{HN}(\mathrm{cm})$} & \multicolumn{2}{|c|}{$T_{\mathrm{w}}\left({ }^{\circ} \mathrm{C}\right)$} & \multicolumn{2}{|c|}{$u\left(\mathrm{~m} \mathrm{~s}^{-1}\right)$} & \multicolumn{2}{|c|}{$\rho\left(\mathrm{kg} \mathrm{m}^{-3}\right)$} & \multicolumn{2}{|c|}{$\rho_{\mathrm{HN}}\left(\mathrm{kg} \mathrm{m}^{-3}\right)$} \\
\hline & no. & & $n_{\mathrm{p}}$ & $n_{\text {th }}$ & mean & median & mean & median & mean & median & mean & median & mean & median \\
\hline \multirow[t]{2}{*}{ KRO } & 1 & 1 Oct 2013-20 May 2015 & 1139 & 91 & 3.2 & 3.1 & -3.9 & -3.0 & 1.1 & 0.9 & 82 & 73 & 73 & 67 \\
\hline & 2 & 1 Oct $2011-30$ Sep 2013 & 1576 & 118 & 3.4 & 3.1 & -4.2 & -4.2 & 1.0 & 0.9 & 87 & 77 & 74 & 69 \\
\hline \multirow[t]{4}{*}{ KTA } & 1 & 1 Oct 2013-20 May 2015 & 579 & 53 & 3.8 & 3.3 & -3.4 & -3.4 & 0.8 & 0.8 & 70 & 69 & 61 & 61 \\
\hline & 2 & 1 Oct $2011-30$ Sep 2013 & 506 & 36 & 3.3 & 2.8 & -4.8 & -4.0 & 0.8 & 0.7 & 75 & 66 & 60 & 54 \\
\hline & 3 & 1 Oct $1999-30$ Sep 2011 & 5293 & 252 & 3.5 & 3.2 & -3.5 & -3.2 & 0.8 & 0.8 & 74 & 74 & 64 & 64 \\
\hline & 4 & 27 Feb 1987-30 Sep 1999 & 7958 & 387 & 3.7 & 3.3 & -3.6 & -3.4 & 0.8 & 0.7 & 74 & 75 & 61 & 59 \\
\hline \multirow[t]{2}{*}{ WAL } & 1 & 1 Oct 2013-20 May 2015 & 1248 & 111 & 3.6 & 3.4 & -4.3 & -4.8 & 1.3 & 1.3 & 76 & 72 & 68 & 66 \\
\hline & 2 & 1 Oct 2011-30 Sep 2013 & 1588 & 126 & 3.9 & 3.5 & -4.3 & -3.6 & 1.7 & 1.7 & 71 & 69 & 62 & 58 \\
\hline WFJ & 1 & 1 Oct 2013-20 May 2015 & 1619 & 100 & 3.0 & 2.7 & -4.9 & -4.0 & 2.2 & 2.0 & 95 & 86 & 91 & 83 \\
\hline
\end{tabular}

tion and for each time period in the Supplement Figs. S01 to S09.

The exclusion of high wind speeds only has a small effect at the lower stations and is more noticeable at the more windexposed stations of Wattener Lizum and Weissfluhjoch. Considering period 1 comprising all stations, the filtering process causes the highest filtering rate for Weissfluhjoch station, with $6 \%$ of data remaining after applying the filtering. The overall highest amount of data reduction is found at Kühtai station, with $5 \%$ of the data remaining after filtering of the longer periods 3 and 4 (Table 2). There was a considerable fraction of data with positive HS changes, a precipitation signal and positive $T_{\mathrm{w}}$. Most of these data seem to be paired with very small HS changes and are eliminated for the final data set when the HN minimum limit is applied.

The correction of the HN underestimation caused by settling of the snowpack during snowfall leads to an average reduction of mean $\rho_{\mathrm{HN}}$ of $10.2 \mathrm{~kg} \mathrm{~m}^{-3}$, with a standard deviation $(\sigma)$ of $2.6 \mathrm{~kg} \mathrm{~m}^{-3}$ (Table 2). This corresponds to $13.5 \%$ with a $\sigma$ of $3.7 \%$. The compaction correction causes noticeably less change in $\rho_{\mathrm{HN}}$ at Weissfluhjoch in period 1 ( $5 \%$ reduction of mean $\rho_{\mathrm{HN}}$ ) than in the other time periods and other stations. The next closest is Kühroint, also in period 1 , with a reduction in $\rho_{\mathrm{HN}}$ of $7 \%$. Unless otherwise stated in the text, $\rho_{\mathrm{HN}}$ always refers to the corrected densities hereafter. Based on a 15-year data set of Weissfluhjoch (WSL Institute for Snow and Avalanche Research SLF, 2015, https://doi.org/10.16904/1) from 1 September 1999 to 31 December 2015, the contribution of settling relative to $\mathrm{HN}$ was calculated using the multi-layer SNOWPACK model (e.g. Lehning et al., 2002) and the approach from Anderson (1976) to compare the results of this study to a more physically based estimate. Results are presented in Fig. 3. While a median relative contribution of settling to $\mathrm{HN}$ by $19 \%$ was calculated with SNOWPACK, the approach of Anderson (1976) resulted in lower values of $5 \%$ in median and $9 \%$ in mean. Thus, the settling considered for the presented data can be

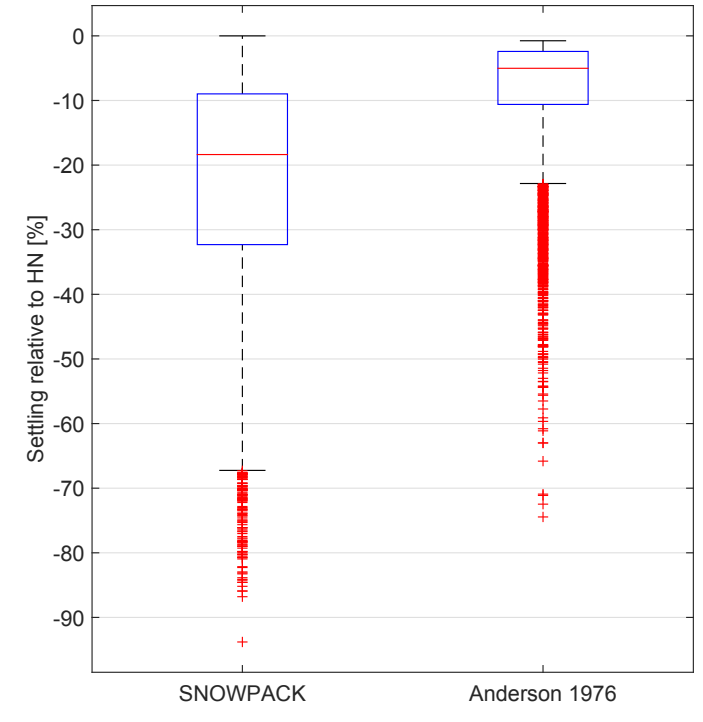

Figure 3. Box plots (median, 25 and $75 \%$ percentiles, $1.5 \times$ interquartile ranges, outliers) of settling relative to hourly new snow heights (HN) modelled with SNOWPACK and using the approach presented by Anderson (1976).

assumed to be a lower estimation. However, higher contributions of settling would result in lower $\rho_{\mathrm{HN}}$ values, with an increased $\mathrm{HN}$ assuming a fixed $\mathrm{HNW}$.

Figure 4 shows the distribution of $\rho_{\mathrm{HN}}$ values obtained from the filtered data at Kühroint station as representative of all stations and periods (Figs. S10 to S17). In general, the $\rho_{\mathrm{HN}}$ values show high variability at all stations. Nevertheless, $\rho_{\mathrm{HN}}$ values are within a reasonable range of less than $200 \mathrm{~kg} \mathrm{~m}^{-3}$. The histograms of $\rho_{\mathrm{HN}}$ show one-tailed distribution towards higher $\rho_{\mathrm{HN}}$. Median $\rho_{\mathrm{HN}}$ values of the different stations and for different periods range between 66 and $86 \mathrm{~kg} \mathrm{~m}^{-3}$ for uncorrected values and between 54 and $83 \mathrm{~kg} \mathrm{~m}^{-3}$ for $\rho_{\mathrm{HN}}$ corrected for settling (Table 2). 

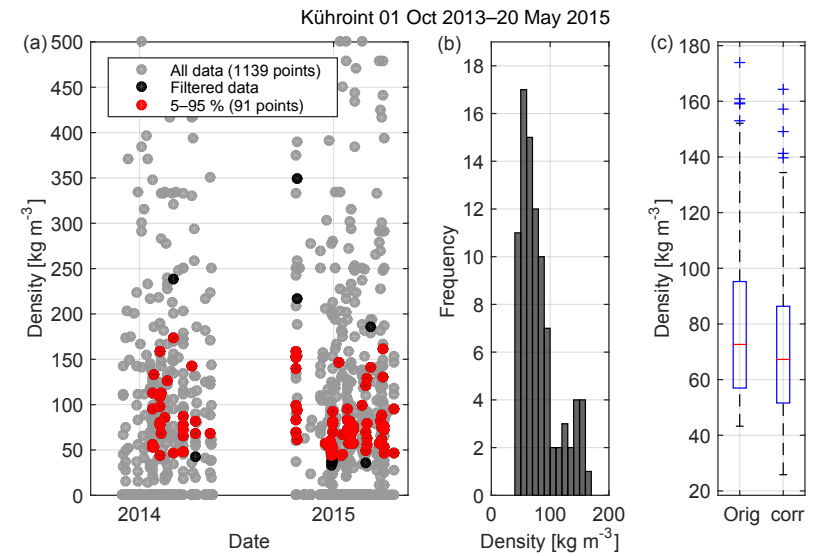

Figure 4. Distribution of calculated new snow densities at Kühroint station for period 1 (1 October 2013-20 May 2015). (a) All data have a precipitation signal and positive HS change, all data are filtered with $\mathrm{HN}>2 \mathrm{~cm}, \mathrm{HNW}>1.5 \mathrm{~mm}, T_{\mathrm{W}}<0{ }^{\circ} \mathrm{C}$ and $u<5 \mathrm{~ms}^{-1}$ ) and filtered data are reduced by cutting off at 5 and $95 \%$ percentiles. (b) Histogram of all filtered densities. (c) The box plot showing the median and 25 and $75 \%$ interquartile range of uncorrected densities and densities corrected for settling of the snowpack. Note that similar figures are available in the Supplement (Figs. S10-S17) for all stations and all time periods considered in this study.

\subsection{Station-dependent differences}

The distributions of $\rho_{\mathrm{HN}}, T_{\mathrm{w}}$ and $u$ during all filtered snowfall data are presented in Figs. 5 and 6 and in Table 2. The lowest $T_{\mathrm{w}}$ and highest wind speeds were observed during snowfall at Weissfluhjoch station. However, the range and distribution of $T_{\mathrm{w}}$ at Weissfluhjoch station result in a higher median $T_{\mathrm{w}}$ during snowfall compared to $T_{\mathrm{w}}$ at Wattener Lizum station. With respect to wind speeds, Wattener Lizum is second. The lowest wind speeds at Kühtai station occur together with the lowest $\rho_{\mathrm{HN}}$. Weissfluhjoch station has the highest median $\rho_{\mathrm{HN}}$ by a large margin with $83 \mathrm{~kg} \mathrm{~m}^{-3}$ in period 1 compared to, respectively, 67,61 and $66 \mathrm{~kg} \mathrm{~m}^{-3}$ at Kühroint, Kühtai and Wattener Lizum stations.

Wind influence may be the reason for higher $\rho_{\mathrm{HN}}$ at Weissfluhjoch station. Snow grains are fragmented by snow drift (e.g. Sato et al., 2008), and thus more packed into the layer of new snow during windy conditions even over the course of only $1 \mathrm{~h}$. The Kühtai station shows the lowest $\rho_{\mathrm{HN}}$, and the difference of the mean $\rho_{\mathrm{HN}}$ is $17 \mathrm{~kg} \mathrm{~m}^{-3}$ between Weissfluhjoch and Kühtai stations for period 1. Median $\rho_{\mathrm{HN}}$ and median $T_{\mathrm{w}}$ of the different periods show a relationship between the periods at Kühtai station, with a higher $\rho_{\mathrm{HN}}$ for a higher $T_{\mathrm{w}}$ (Fig. 6, Table 2).

The overall mean hourly $\rho_{\mathrm{HN}}$ of all stations and time periods is $68 \mathrm{~kg} \mathrm{~m}^{-3}$, with a standard deviation of $9 \mathrm{~kg} \mathrm{~m}^{-3}$. In general, this is considerably lower than new snow densities from daily measurements (e.g. Roebber et al., 2003; Egli et al., 2009; Teutsch, 2009). Meister (1985) measured $\rho_{\mathrm{HN}}$

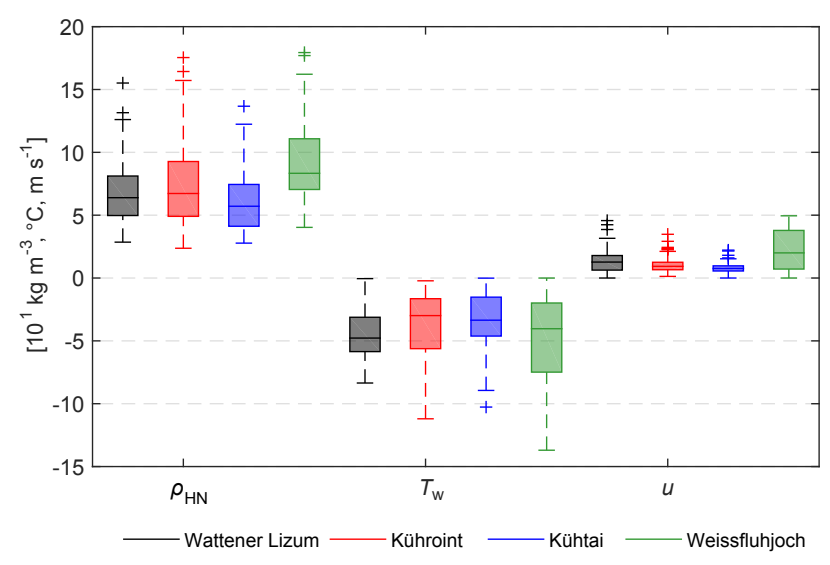

Figure 5. Box plot (median, 25 and $75 \%$ percentiles, $1.5 \times$ interquartile ranges, outliers) of calculated new snow densities $\left(\rho_{\mathrm{HN}}\right)$ based on observations, wet bulb temperature $\left(T_{\mathrm{W}}\right)$ and wind speed $(u)$ for filtered snowfall events (Table 2) at all four stations within period 1 (1 October 2013-20 May 2015).

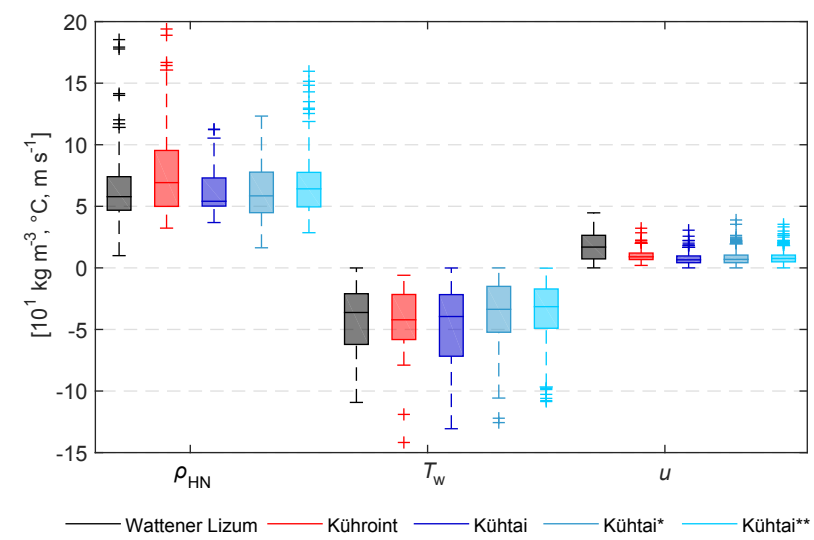

Figure 6. Box plots (median, 25 and $75 \%$ percentiles, $1.5 \times$ interquartile ranges, outliers) of calculated new snow densities $\left(\rho_{\mathrm{HN}}\right)$ based on observations, wet bulb temperature $\left(T_{\mathrm{W}}\right)$ and wind speed $(u)$ for filtered snowfall events (Table 2 ) at three stations within period 2 (1 October 2011-1 October 2013) and at Kühtai station within period 3 (index*, 1 October 1999-30 September 2011) and period 4 (index**, 27 February 1987-30 September 1999).

lower than $100 \mathrm{~kg} \mathrm{~m}^{-3}$ on a daily basis, analysing data with a $\mathrm{HN}$ of more than $0.1 \mathrm{~m}$. In contrast, the presented $\rho_{\mathrm{HN}}$ values are closer to the time of the snowfall event, and density changes over several hours due to e.g. energy exchanges and wind drift at the uppermost snow layer can be excluded. On the basis of $\rho_{\mathrm{HN}}$ in situ measurements in hourly resolution Lehning et al. (2002) emphasized that at sub-daily time intervals, lower densities in comparison to daily new snow densities have to be applied. Comparatively low $\rho_{\mathrm{HN}}$ values close to $50 \mathrm{~kg} \mathrm{~m}^{-3}$ were also presented by Ishizaka et al. (2016), with an average $\rho_{\mathrm{HN}}$ of $52 \mathrm{~kg} \mathrm{~m}^{-3}$ for aggregated snowflakes and $55 \mathrm{~kg} \mathrm{~m}^{-3}$ for small hydrometeors. They further found a 


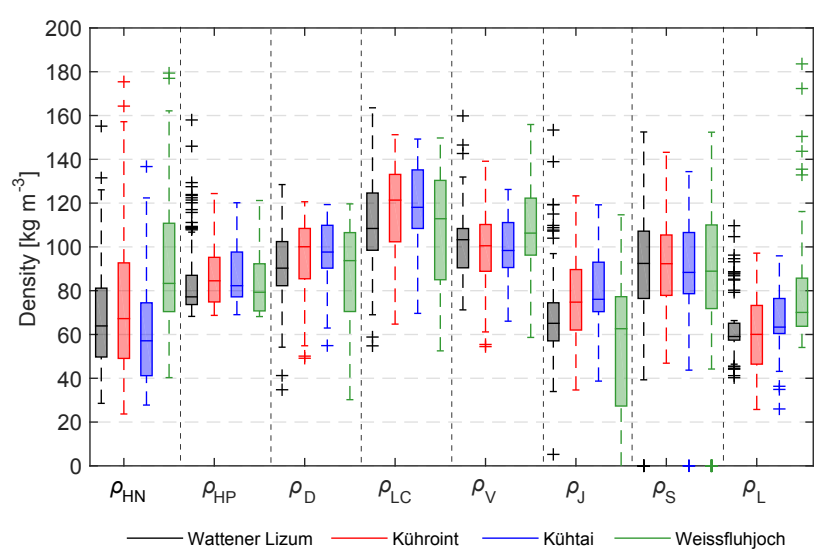

Figure 7. Box plots (median, 25 and $75 \%$ percentiles, $1.5 \times$ interquartile ranges, outliers) of calculated new snow densities $\left(\rho_{\mathrm{HN}}\right)$ based on observations and densities calculated using parameterizations developed in previous studies (Eqs. 3-9) at all four stations within period 1 (1 October 2013-20 May 2015).

mean $\rho_{\mathrm{HN}}$ of $72 \mathrm{~kg} \mathrm{~m}^{-3}$ for a second group of smaller crystals and $99.4 \mathrm{~kg} \mathrm{~m}^{-3}$ for graupel-type hydrometeors.

The observed inter-station variability shows the importance of differing $\rho_{\mathrm{HN}}$ between more windy mountain stations and less windy stations in the valleys.

\subsection{Density parameterizations}

A simple linear regression analysis showed that the shortterm variability of $\rho_{\mathrm{HN}}$ cannot be explained with corresponding changes in $T_{\mathrm{w}}$ or $u$ (Table 3, Figs. 7 and S18 to S26). An increase of $\rho_{\mathrm{HN}}$ with increasing $T_{\mathrm{W}}$ can be identified in the figures, and the slopes of the least squares regressions show an increase of $\rho_{\mathrm{HN}}$ with an increase of wet bulb temperature for all stations (Table 3). However, no consistent relationship between $\rho_{\mathrm{HN}}$ and $u$ could be found, either for single stations or for different periods at one station. The binned analysis based on $T_{\mathrm{w}}$ showed a considerable $r^{2}$ of more than 0.5 on a 0.01 significance level at Kühroint and Kühtai station, with intercepts of 70 to $80 \mathrm{~kg} \mathrm{~m}^{-3}$ and gradients of about 3 to $4 \mathrm{~kg} \mathrm{~m}^{-3}$ per $1^{\circ} \mathrm{C}$.

Although the regressions generally show the expected trends, it must be noted that the variability of $\rho_{\mathrm{HN}}$ remains unexplained. This could partly be attributed to the measurement uncertainties. However, the variability caused by measurement uncertainties is assumed to be equalized, only considering the mean and median of $\rho_{\mathrm{HN}}$ values for total time periods. Relationships between $\rho_{\mathrm{HN}}$ and $T_{\mathrm{W}}$ were recognized for distinct periods and stations only, but with similar coefficients of determination in comparison to the results of e.g. Judson and Doesken (2000), Wetzel et al. (2004) or Wright et al. (2016).

Testing multiple regressions using additional meteorological parameters did not increase the statistical significance.

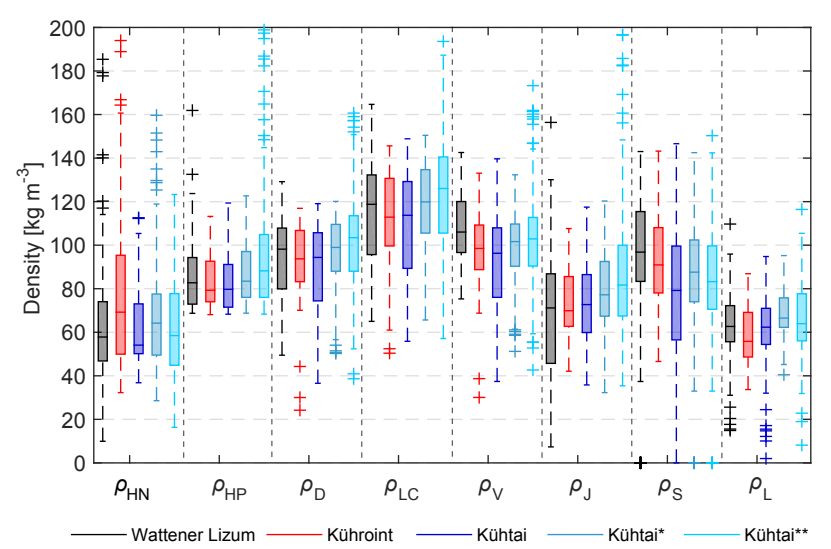

Figure 8. Box plots (median, 25 and $75 \%$ percentiles, $1.5 \times$ interquartile ranges, outliers) of calculated new snow densities $\left(\rho_{\mathrm{HN}}\right)$ based on observations and densities calculated using parameterizations developed in previous studies (Eqs. 3-9) at three stations within period 2 (1 October 2011-1 October 2013) and at Kühtai station within period 3 (index*, 1 October 1999-30 September 2011) and period 4 (index**, 27 February 1987-30 September 1999).

Instead, a comparison to existing parameterizations of $\rho_{\mathrm{HN}}$ was performed for all stations and periods.

Considering the various parameterizations, which use meteorological parameters to approximate new snow density (Eqs. 3 to 9), it is evident that the observed variability of $\rho_{\mathrm{HN}}$ is not correlated to the variability of parameterized new snow densities (Table 4). Most of the seven parameterizations overestimate the median of the observed $\rho_{\text {HN }}$ values (Figs. 3, 7 and 8 and Table 4). However, some parameterizations produce considerably better results than others for median $\rho_{\mathrm{HN}}$ values. The parameterizations of LaChapelle (1962), Diamond and Lowry (1954) and Vionnet et al. (2012) consistently overestimate $\rho_{\mathrm{HN}}$. The parameterization of Hedstrom and Pomeroy (1998) overestimates $\rho_{\mathrm{HN}}$ at Kühroint, Kühtai and Wattener Lizum stations (Figs. 7 and 8 ), but converges with the median $\rho_{\mathrm{HN}}$ at Weissfluhjoch station for period 1 (Fig. 7, Table 4). In general, the $\rho_{\mathrm{HN}}$ values simulated using the parameterization of Jordan et al. (1999) are closer to calculated $\rho_{\mathrm{HN}}$, but median $\rho_{\mathrm{HN}}$ values are underestimated for Weissfluhjoch station. Median $\rho_{\mathrm{HN}}$ values and the range of $\rho_{\mathrm{HN}}$ at Weissfluhjoch are well simulated using the parameterization of Schmucki et al. (2014), but it overestimates median $\rho_{\mathrm{HN}}$ of Kühroint, Kühtai and Wattener Lizum stations (Figs. 3 and 7 and Table 4). However, this parameterization was fitted to original density data from Weissfluhjoch.

The lowest root mean squared error (RMSE) was achieved for Weissfluhjoch station with the parameterization of Diamond and Lowry (1954). The parameterizations of Lehning et al. (2002) and Jordan et al. (1999) result in the lowest RMSE (Table 4) compared to $\rho_{\mathrm{HN}}$ at Kühroint, Kühtai and 
Table 3. Results of a single linear regression between the corrected densities $\left(\rho_{\mathrm{HN}}\right)$ as a dependent variable and wet bulb temperature $\left(T_{\mathrm{W}}\right)$ and wind speed $(u)$ as explanatory variables for the class median values based on all filtered data points binned into $0.5^{\circ} \mathrm{K}$ classes and classes of $0.5 \mathrm{~ms}^{-1}$, respectively. The corresponding coefficient of determination $\left(r^{2}\right)$ and the $p$ value are presented.

\begin{tabular}{lrrrr|rrrrr}
\hline \multirow{2}{*}{ Station } & Period no. & \multicolumn{5}{c}{$T_{\mathrm{w}}$} & \multicolumn{4}{c}{$u$} \\
\cline { 3 - 10 } & & Intercept & $\delta \rho / \delta T_{\mathrm{W}}$ & $r^{2}$ & $p$ & Intercept & $\delta \rho / \delta u$ & $r^{2}$ & $p$ \\
\hline \multirow{2}{*}{ KRO } & 1 & 82.07 & 4.00 & 0.65 & 0.00 & 45.12 & 19.10 & 0.35 & 0.16 \\
& 2 & 76.54 & 0.99 & 0.11 & 0.35 & 64.84 & 1.29 & 0.00 & 0.90 \\
\hline \multirow{2}{*}{ KTA } & 1 & 66.37 & 1.84 & 0.12 & 0.44 & 72.59 & -14.44 & 0.41 & 0.36 \\
& 2 & 55.15 & -0.37 & 0.02 & 0.75 & 54.25 & 3.37 & 0.53 & 0.17 \\
& 3 & 68.18 & 1.51 & 0.56 & 0.01 & 64.81 & -3.82 & 0.39 & 0.10 \\
& 4 & 72.41 & 3.75 & 0.82 & 0.00 & 49.31 & 9.41 & 0.30 & 0.26 \\
\hline \multirow{2}{*}{ WAL } & 1 & 78.84 & 2.88 & 0.47 & 0.06 & 65.28 & 1.32 & 0.02 & 0.71 \\
& 2 & 64.58 & 0.97 & 0.17 & 0.21 & 59.43 & 1.50 & 0.05 & 0.57 \\
\hline \multirow{2}{*}{ WFJ } & 1 & 92.68 & 0.71 & 0.04 & 0.53 & 92.88 & -2.91 & 0.18 & 0.23 \\
\hline
\end{tabular}

Wattener Lizum stations, with slightly lower density values using the parameterization of Lehning et al. (2002) fitting best to the low median $\rho_{\mathrm{HN}}$ values of the Kühtai station.

Thus, the parameterization of Lehning et al. (2002) appears to be the first choice regarding the calculation of hourly new snow densities for high elevations and inner-alpine regions. This parameterization requires multiple input parameters. Where such data are not available, the parameterization of Jordan et al. (1999), requiring temperature and wind data only, might be a good alternative. Even though correlations are low in general, some of the highest Pearson correlation values ( $r$, Table 4$)$ were achieved by applying the simpler, linear equations by Diamond and Lowry (1954), LaChapelle (1962) and Vionnet et al. (2012). In addition to the regressions presented in Table 3, this shows again the identifiable relation between snow density and temperature.

Mair et al. (2016) evaluated some of the parameterizations also considered in this study. Using a distinctly larger time window for smoothing their HS data ( $5 \mathrm{~h}$ average), they calculated median $\rho_{\mathrm{HN}}$ between 75 and $100 \mathrm{~kg} \mathrm{~m}^{-3}$ using the parameterizations of Jordan et al. (1999) and Hedstrom and Pomeroy (1998), which is close to the results presented in this study. They also found that using the parameterization of LaChapelle (1962) results in a mean $\rho_{\mathrm{HN}}$ higher than $100 \mathrm{~kg} \mathrm{~m}^{-3}$. In general they concluded that using a constant $\rho_{\mathrm{HN}}$ of $100 \mathrm{~kg} \mathrm{~m}^{-3}$ caused an overestimation of seasonal precipitation by up to $30 \%$. Conversely, a mean $\rho_{\mathrm{HN}}$ of $70 \mathrm{~kg} \mathrm{~m}^{-3}$ will result in better SWE estimations. This is in accordance with the resulting average $\rho_{\mathrm{HN}}$ of $68 \mathrm{~kg} \mathrm{~m}^{-3}$ calculated from automated measurements within our study.

\section{Conclusion}

The aim of this study was to assess the value of automated measurements of snow depth (HS) and snow water equiva- lent (SWE) to compute new snow density $\left(\rho_{\mathrm{HN}}\right)$ on an hourly time interval. Complementary data sets of HS and SWE measurements using ultrasonic devices and snow pillows from four mountain stations were used to calculate the height of new snow (HN) and the water equivalent of snowfall (HNW). Subsequently, $\rho_{\mathrm{HN}}$ was calculated from HN and HNW, considering potential underestimation of $\mathrm{HN}$ by settling of the snowpack.

The snow measurements using ultrasonic devices and snow pillows were found to be appropriate for the calculation of station average hourly $\rho_{\mathrm{HN}}$ values. However, the observed variability in $\rho_{\mathrm{HN}}$ from the automated measurements could not be described with appropriate statistical significance by any of the investigated algorithms. An average $\rho_{\mathrm{HN}}$ of $68 \mathrm{~kg} \mathrm{~m}^{-3}$ with a standard deviation of $9 \mathrm{~kg} \mathrm{~m}^{-3}$ was calculated considering all stations and time periods. The average $\rho_{\mathrm{HN}}$ for individual stations in a common period ranged from 61 to $83 \mathrm{~kg} \mathrm{~m}^{-3}$, with a higher $\rho_{\mathrm{HN}}$ at more windy locations. Thus, wind speed is a crucial parameter for the inter-station variability of $\rho_{\mathrm{HN}}$.

Seven existing parameterizations for estimating new snow densities were tested, and most calculations overestimate $\rho_{\mathrm{HN}}$ in comparison to the results from the hourly automated measurements. Two of the tested parameterizations were capable of simulating low $\rho_{\mathrm{HN}}$ at sheltered inner-alpine stations. This reveals that it has to be carefully considered which parameterization should be used for which application and environment.

Nevertheless, the natural variability of $\rho_{\mathrm{HN}}$ is masked using the combination of ultrasonic ranging and snow pillow data for $\rho_{\mathrm{HN}}$ calculation because of the limited accuracy of the sensors and snow depth changes due to settling of the snowpack and wind drift. We conclude that the value of the analysed data is given by the mean and median $\rho_{\mathrm{HN}}$ and its variation between different stations and time periods, and the 


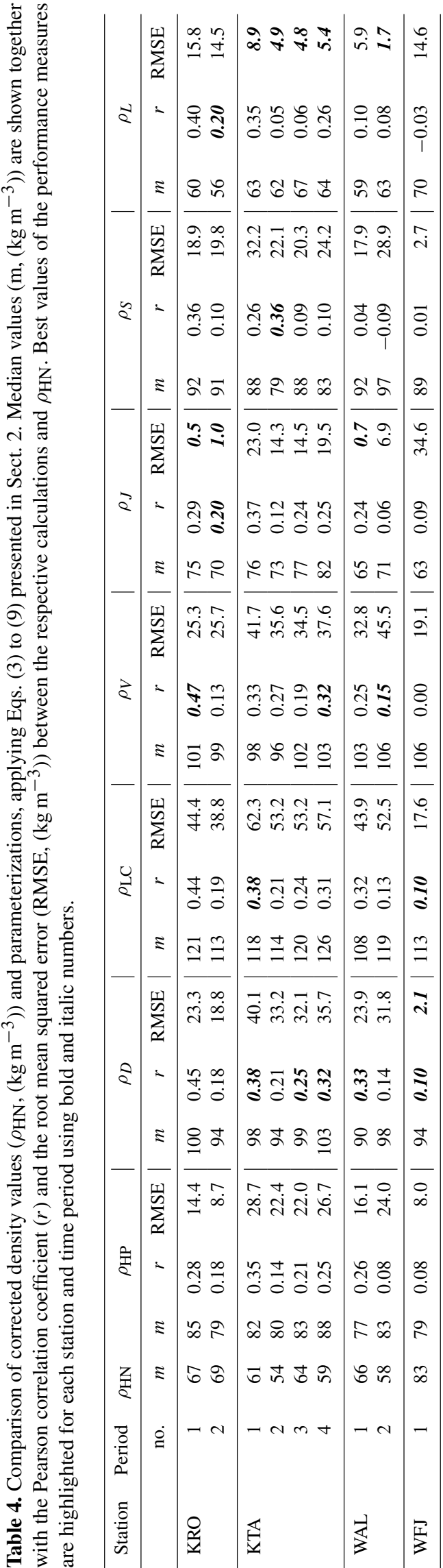

considerably lower $\rho_{\mathrm{HN}}$ values in contrast to $\rho_{\mathrm{HN}}$ calculated on daily or event-based measurements.

The study shows the potential of collocated measurements of HS and SWE for determining $\rho_{\mathrm{HN}}$ automatically. However, recent developments in optical distance sensors and weighing devices increase the accuracy of such snow measurements and hence decrease the uncertainty of subsequent calculations. We therefore recommend the use of highaccuracy sensors for the determination of $\rho_{\mathrm{HN}}$ at sub-daily intervals.

Data availability. A processed set of SNOWPACK input data from Weissfluhjoch station is available in WSL Institute for Snow and Avalanche Research SLF (2015) (WFJ_MOD: Meteorological and snowpack measurements from Weissfluhjoch, Davos, Switzerland) at https://doi.org/10.16904/1.

Detailed information about the Weissfluhjoch data set can be found in WSL Institute for Snow and Avalanche Research SLF (2015) and in Marty and Meister (2012). Data of Kühtai station are published by Krajči et al. (2017) and are available from the Zenodo repository at https://doi.org/10.5281/zenodo.556110 (Parajka, 2017).

Data of Kühroint station are available on request from the Bavarian Avalanche Warning Service (https://www. lawinenwarndienst-bayern.de/organisation/lawinenwarnzentrale/ kontakt.php, last access: 2 May 2018).

Data of Wattener Lizum station are available on request from the Austrian Federal Research and Training Centre for Forests, Natural Hazards and Landscape (BFW; https://bfw.ac.at/rz/bfwcms. web?dok=6057, last access: 2 May 2018).

Supplement. The supplement related to this article is available online at: https://doi.org/10.5194/hess-22-2655-2018-supplement.

Author contributions. $\mathrm{KH}$ is the main investigator of this study. $\mathrm{LH}$ performed snow density analysis within the pluSnow project. RK performed initial quality control, provision and set-up of the project database for all station and meta-data. CM prepared the data of Weissfluhjoch station, contributed fruitful discussions and helped to hone the focus of the analysis and the manuscript. MO contributed significantly to analysis and discussions as the main project partner within the framework of the pluSnow project.

Competing interests. The authors declare that they have no conflict of interest.

Acknowledgements. The pluSnow project is financed by the Gottfried and Vera Weiss Science Foundation (WWW). The project funding is managed in trust by the Austrian Science Fund (FWF): P 28099-N34. The project duration was October 2015September 2018. The authors want to thank the colleagues of the Tiroler Wasserkraft AG (TIWAG), of the Federal Research and Training Centre for Forests (BFW) and of the Bavarian Avalanche 
Warning Service for data provision. In particular we are grateful for the close collaboration with Johannes Schöber (TIWAG) and Reinhard Fromm (BFW). We also want to thank Michael Lehning, Charles Fierz and the two reviewers for their helpful comments and fruitful discussion of the results.

Edited by: Thom Bogaard

Reviewed by: two anonymous referees

\section{References}

Alcott, T. I. and Steenburgh, W. J. : Snow-to-Liquid Ratio Variability and Prediction at a High-Elevation Site in Utah's Wasatch Mountains, Weather Forecast., 25, 323-337, https://doi.org/10.1175/2009WAF2222311.1, 2010.

Anderson, E. A.: A point energy and mass balance model of a snow cover, NOAA Tech. Rep. NWS-19, 150 pp., 1976.

Buisán, S. T., Earle, M. E., Collado, J. L., Kochendorfer, J., Alastrué, J., Wolff, M., Smith, C. D., and López-Moreno, J. I.: Assessment of snowfall accumulation underestimation by tipping bucket gauges in the Spanish operational network, Atmos. Meas. Tech., 10, 1079-1091, https://doi.org/10.5194/amt10-1079-2017, 2017.

Diamond, M. and Lowry, W. P.: Correlation of density of new snow with 700-millibar temperature, J. Meteorol., 11, 512-513, 1954.

Egli, L., Jonas, T., and Meister, R.: Comparison of different automatic methods for estimating snow water equivalent, Cold Reg. Sci. Technol., 57, 107-115, https://doi.org/10.1016/j.coldregions.2009.02.008, 2009.

Fierz, C., Armstrong, R. L., Durand, Y., Etchevers, P., Greene, E., McClung, D. M., Nishimura, K., Satyawali, P. K., and Sokratov S. A.: The International Classification for Seasonal Snow on the Ground, IHP-VII Technical Documents in Hydrology No. 83, IACS Contribution No. 1, UNESCO-IHP, Paris, 2009.

Gold, L. W. and Power, B. A.: Correlation of snow crystal type with estimated temperature of formation, J. Meteorol., 9, 447-447, https://doi.org/10.1175/15200469(1952)009<0448:COSCTW>2.0.CO;2, 1952.

Goodison, B. E., Wilson, B., We, K., and Metcalfe, J. R.: An inexpensive remote snow depth gauge: an assessment, The 52th Western Snow Conference, Sun Valley, Idaho, 17-19 April 1984.

Goodison, B. E., Louie, P. Y. T., and Yang, D.: WMO solid precipitation measurement intercomparison. Final Report, World Meteorological Organization, No. 872, 212 pp., 1998.

Gubler, H.: An Inexpensive Remote Snow-Depth Gauge based on Ultrasonic Wave Reflection from the Snow Surface, J. Glaciol., 27, 157-163, https://doi.org/10.3189/S002214300001131X, 1981.

Hedstrom, N. R. and Pomeroy, J. W.: Measurements and modeling of snow interception in the boreal forest, Hydrol. Process., 12, 1611-1625, https://doi.org/10.1002/(SICI)10991085(199808/09)12:10/11<1611::AID-HYP684>3.0.CO;2-4, 1998.

Heilig, A., Schneebeli, M., and Eisen, O.: Upwardlooking ground-penetrating radar for monitoring snowpack stratigraphy, Cold Reg. Sci. Technol., 59, 152-162, https://doi.org/10.1016/j.coldregions.2009.07.008, 2009.
Helfricht, K., Koch, R., Hartl, L., and Olefs, M.: Potential and Challenges of an extensive operational use of high accuracy optical snow depth sensors to minimize solid precipitation undercatch, Proceedings of the 16th International Snow Science Workshop ISSW, Breckenridge, Colorado, 3-7 October 2016, 631635, 2016.

Ishizaka, M., Motoyoshi, H., Yamaguchi, S., Nakai, S., Shiina, T., and Muramoto, K.-I.: Relationships between snowfall density and solid hydrometeors, based on measured size and fall speed, for snowpack modeling applications, The Cryosphere, 10, 28312845, https://doi.org/10.5194/tc-10-2831-2016, 2016.

Johnson, J. B. and Schaefer, G. L.: The influence of thermal, hydrologic, and snow deformation mechanisms on snow water equivalent pressure sensor accuracy, Hydrol. Process., 16, 3529-3542, https://doi.org/10.1002/hyp.1236, 2002.

Jordan, R. E., Andreasand, E. L., and Makshtas, A. P.: Heat budget of snow-covered sea ice at North Pole, J. Geophys. Res., 104, 7785-7806, https://doi.org/10.1029/1999JC900011, 1999.

Judson, A.: The weather and climate of a high mountain pass in the Colorado Rockies, Research Paper RM-16, USDA Forest Service, Fort Collins, CO, 28 pp., 1965.

Judson, A. and Doesken, N.: Density of Freshly Fallen Snow in the Central Rocky Mountains, B. Am. Meteorol. Soc., 81, 1577-1587, https://doi.org/10.1175/15200477(2000)081<1577:DOFFSI>2.3.CO;2, 2000.

Koch, F., Prasch, M., Schmid, L., Schweizer, J., and Mauser, W.: Measuring Snow Liquid Water Content with Low-Cost GPS Receivers, Sensors, 14, 20975-20999, https://doi.org/10.3390/s141120975, 2014.

Krajči, P., Kirnbauer, R., Parajka, J., Schöber, J., and Blöschl G.: The Kühtai data set: 25 years of lysimetric, snow pillow, and meteorological measurements, Water Resour. Res., 53, 5158-5165, https://doi.org/10.1002/2017WR020445, 2017.

LaChapelle, E. R.: The density distribution of new snow, USDA Forest Service, Alta Avalanche Study Center, Project F, Progress Rep. 2, Salt Lake City, UT, 13 pp., 1962.

Lehning, M., Bartelt, P., Brown, B., and Fierz, C.: A physical SNOWPACK model for the Swiss avalanche warning. Part III: meteorological forcing, thin layer formation and evaluation, Cold Reg. Sci. Technol., 35, 169-184, https://doi.org/10.1016/S0165232X(02)00072-1, 2002.

Lundberg, A., Granlund, N., and Gustafsson, D.: Towards automated "Ground truth" snow measurements: a review of operational and new measurement methods for Sweden, Norway, and Finland, Hydrol. Process., 24, 1955-1970, https://doi.org/10.1002/hyp.7658, 2010.

Mair, E., Leitinger, G., Della Chiesa, S., Niedrist, G., Tappeiner, U., and Bertoldi, G.: A simple method to combine snow height and meteorological observations to estimate winter precipitation at sub-daily resolution, Hydrolog. Sci. J., 61, 2050-2060, https://doi.org/10.1080/02626667.2015.1081203, 2016.

Mair, M. and Baumgartner, D. J.: Operational experience with automatic snow depth sensors - ultrasonic and laser principle, TECO, WMO, Helsinki, Finland, WMO, 2010.

Marty, C. and Meister, R.: Long-term snow and weather observations at Weissfluhjoch and its relation to other high-altitude observatories in the Alps, Theor. Appl. Climatol., 110, 573-583, https://doi.org/10.1007/s00704-012-0584-3, 2012. 
McCreight, J. L., Small, E. E., and Larson, K. M.: Snow depth, density, and SWE estimates derived from GPS reflection data: Validation in the western U. S., Water Resour. Res., 50, 68926909, https://doi.org/10.1002/2014WR015561, 2014.

McKay, G. A. and Gray, D. M.: The distribution of snow cover. In Handbook of Snow. Principles, Processes, Management and Use, edited by: Gray, D. M. and Male, D. H., Pergamon Press, Toronto, 1981.

Meister, R.: Density of New Snow and its Dependence of Air Temperature and Wind, Workshop on the Correction of Precipitation Measurements, 1-3 April 1985, Zurich, Volume: B, edited by: Sevruk, B., Correction of Precipitation Measurements, Zürcher Geographische Schriften, No. 23, 1985.

Morin, S., Lejeune, Y., Lesaffre, B., Panel, J.-M., Poncet, D., David, P., and Sudul, M.: An 18-yr long (1993-2011) snow and meteorological dataset from a mid-altitude mountain site (Col de Porte, France, $1325 \mathrm{~m}$ alt.) for driving and evaluating snowpack models, Earth Syst. Sci. Data, 4, 13-21, https://doi.org/10.5194/essd4-13-2012, 2012.

Nakaya, U.: The Formation of Ice Crystals, in: Compendium of Meteorology, edited by: Malone, T. F., American Meteorological Society, Boston, MA, 207-220, https://doi.org/10.1007/9781-940033-70-9_18, 1951.

Nitu, R., Aulamo, O., Baker, B., Earle, M., Goodison, B., Hoover, J., Hendrikx, J., Joe, P., Kochendorfer, J., Laine, T., Lanza, L., Landolt, S., Rasmussen, R., Roulet, Y. A., Smith, C., Samanter, A., Sabatini, F., Vuerich, E., Vuglinsky, V., Wolff, M., and Yang, D.: WMO Intercomparison of instruments and methods for the measurement of precipitiation and snow on the ground, in: 9th International Workshop on Precipitation in Urban Areas, 6. St. Moritz, Switzerland, 2012.

Olefs, M., Fischer, A., and Lang, J.: Boundary conditions for artificial snow production in the Austrian Alps, J. Appl. Meteorol. Clim., 49, 1096-113, https://doi.org/10.1175/2010JAMC2251.1, 2010.

Olefs, M., Schöner, W., Suklitsch, M., Wittmann, C., Niedermoser, B., Neururer, A., and Wurzer. A.: SNOWGRID - A New Operational Snow Cover Model in Austria, in: International Snow Science Workshop, Grenoble - Chamonix Mont-Blanc, 2013.

Pahaut, E.: La métamorphose des cristaux de neige (Snow crystal metamorphosis), 96, Monographies de la Météorologie Nationale, Météo France, 1976.

Pan, X., Yang, D., Li, Y., Barr, A., Helgason, W., Hayashi, M., Marsh, P., Pomeroy, J., and Janowicz, R. J.: Bias corrections of precipitation measurements across experimental sites in different ecoclimatic regions of western Canada, The Cryosphere, 10, 2347-2360, https://doi.org/10.5194/tc-10-2347-2016, 2016.

Parajka, J.: The Kühtai dataset: 25 years of lysimetric, snow pillow and meteorological measurements https://doi.org/10.5281/zenodo.556110, 2017.

Power, B. A., Summers, P. W., and D'Avignon, J.: Snow crystal forms and riming effect as related to snowfall density and general storm conditions, J. Atmos. Sci., 21, 300-305, https://doi.org/10.1175/15200469(1964)021<0300:SCFARE>2.0.CO;2, 1964.

Roebber, P. J., Bruening, S. L., Schultz, D. M., and Cortinas, J.V.: Improving Snowfall Forecasting by Diagnosing Snow Density, Weather Forecast., 18, 264-287, https://doi.org/10.1175/15200434(2003)018<0264:ISFBDS>2.0.CO;2, 2003.
Ryan, W. A., Doesken, N. J., and Fassnacht, S. R.: Evaluation of Ultrasonic Snow Depth Sensors for U.S. Snow Measurements, J. Atmos. Ocean. Tech., 25, 667-684, https://doi.org/10.1175/2007JTECHA947.1, 2008.

Sato, T., Kosugi, K., Mochizuki, S., and Nemoto, M.: Wind speed dependences of fracture and accumulation of snowflakes on snow surface, Cold Reg. Sci. Technol., 51, 229-239, https://doi.org/10.1016/j.coldregions.2007.05.004, 2008.

Schattan, P., Baroni, G., Oswald, S. E., Schöber, J., Fey, C., Kormann, C., Huttenlau, M., and Achleitner, S.: Continuous Monitoring of Snowpack Dynamics in Alpine Terrain by AboveGround Neutron Sensing, Water Resour. Res., 53, 1-20, 2017.

Schmid, L., Koch, F., Heilig, A., Prasch, M., Eisen, O., Mauser, W., and Schweizer, J.: A novel sensor combination (upGPR-GPS) to continuously and nondestructively derive snow cover properties, Geophys. Res. Lett., 42, 3397-3405, https://doi.org/10.1002/2015GL063732, 2015.

Schmid, L., Heilig, A., Mitterer, C., Schweizer, J., Maurer, H., Okorn, R., and Eisen, O.: Continuous snowpack monitoring using upward-looking ground-penetrating radar technology, J. Glaciol., 60, 509-525, https://doi.org/10.3189/2014JoG13J084, 2014.

Schmidt, R. A. and Gluns, D. R.: Snowfall interception on branches of three conifer species, Can. J. Forest Res., 21, 1262-1269, https://doi.org/10.1139/x91-176, 1991.

Schmucki, E., Marty, C., Fierz, C., and Lehning, M.: Evaluation of modelled snow depth and snow water equivalent at three contrasting sites in Switzerland using SNOWPACK simulations driven by different meteorological data input, Cold Reg. Sci. Technol., 99, 27-37, https://doi.org/10.1016/j.coldregions.2013.12.004, 2014.

Schöber, J., Achleitner, S., Bellinger, J., Kirnbauer, R., and Schöberl, F.: Analysis and modelling of snow bulk density in the Tyrolean Alps., Hydrol. Res., 47, 419-441, https://doi.org/10.2166/nh.2015.132, 2016.

Serreze, M. C., Clark, M. P., Armstrong, R. L., McGinnis, D. A., and Pulwarty, R. S.: Characteristics of the western United States snowpack from snowpack telemetry (SNOTEL) data, Water Resour. Res., 35, 2145-2160, https://doi.org/10.1029/1999WR900090, 1999.

Simeral, D. B.: New snow density across an elevation gradient in the Park Range of northwestern Colorado, M.A. thesis, Department of Geography, Planning and Recreation, Northern Arizona University, 101 pp., 2005.

Smith, C. D., Kontu, A., Laffin, R., and Pomeroy, J. W.: An assessment of two automated snow water equivalent instruments during the WMO Solid Precipitation Intercomparison Experiment, The Cryosphere, 11, 101-116, https://doi.org/10.5194/tc11-101-2017, 2017.

Sonntag, D.: Important new values of the physical constants of 1986, vapour pressure formulations based on the ITS-90, and psychrometer formulae, Z. Meteorol., 70, 340-344, 1990.

Steinkogler, W.: Systematic Assessment of New Snow Settlement in SNOWPACK, MA thesis, University of Innsbruck, Institute of Meteorology and Geophysics, 96 pp., 2009.

Teutsch, C.: Neuschneedichtenanalyse in den Ostalpen, MA thesis, Institute of Meteorology and Geophysics, Innsbruck, Austria, University of Innsbruck, 2009. 
US Army Corps of Engineers: Snow Hydrology: Summary Report of the Snow Investigations, North Pacific Division, Portland, Oregon, 437 pp., 1956.

Valt, M., Chiambretti, I., and Dellavedova, P.: Fresh snow density on the Italian Alps, Geophysical Research Abstracts, 16, EGU20149715, 2014.

Vionnet, V., Brun, E., Morin, S., Boone, A., Faroux, S., Le Moigne, P., Martin, E., and Willemet, J.-M.: The detailed snowpack scheme Crocus and its implementation in SURFEX v7.2, Geosci. Model Dev., 5, 773-791, https://doi.org/10.5194/gmd-5773-2012, 2012.

Wetzel, M., Meyers, M., Borys, R., McAnelly, R., Cotton, W., Rossi, A., Frisbie, P., Nadler, D., Lowenthal, D., Cohn, S., and Brown, W.: Mesoscale Snowfall Prediction and Verification in Mountainous Terrain, Weather Forecast., 19, 806-828, https://doi.org/10.1175/15200434(2004)019<0806:MSPAVI>2.0.CO;2, 2004.
Wright, P. J., Comey, B., McCollister, C., and Rheam, M.: Estimation of the new snow density using 42 seasons of meteorological data from Jackson Hole Mountain Resort, Wyoming, Proceedings, International Snow Science Workshop, Breckenridge, Colorado, 1180-1185, 2016.

WSL Institute for Snow and Avalanche Research SLF: WFJ_MOD: Meteorological and snowpack measurements from Weissfluhjoch, Davos, Switzerland, WSL Institute for Snow and Avalanche Research SLF, https://doi.org/10.16904/1, 2015. 